\title{
Dysfunctional lamins as mediators of oxidative stress in Emery-Dreifuss muscular dystrophy
}

\author{
Irena Niebroj-Dobosz ${ }^{1}$, Beata Sokołowska², Agnieszka Madej-Pilarczyk ${ }^{1}$, Michał Marchel ${ }^{3}$, \\ Irena Hausmanowa-Petrusewicz ${ }^{1}$ \\ ${ }^{1}$ Neuromuscular Unit, Mossakowski Medical Research Centre, Polish Academy of Sciences, Warsaw, ${ }^{2}$ Bioinformatics Laboratory, \\ Mossakowski Medical Research Centre, Polish Academy of Sciences, Warsaw, ${ }^{3} 1^{\text {st }}$ Department of Cardiology, Medical University \\ of Warsaw, Warsaw, Poland
}

\begin{abstract}
Deficit of lamin A/C or emerin causes genetically transmitted Emery-Dreifuss muscular dystrophy (EDMD). As lamins are considered to be mediators of oxidative stress, the antioxidant/oxidant status was examined. The total oxidant/ antioxidant status in serum was examined in 29 cases of Emery-Dreifuss muscular dystrophy. The study included 12 autosomal-dominant laminopathies (AD-EDMD), 17 X-linked emerinopathies (X-EDMD) and 20 age-matched normal subjects. Total oxidant status (TOS) was reduced in all cases, and the total antioxidant capacity (TAC) was found to be decreased in the majority of the patients (in 82.8\%). A relationship between TOS level and disease progression was noted. No correlation between TOS/TAC level and cardiological or neurological parameters was detected.

The results of the study indicate disturbances of redox balance in EDMD patients. Determination of TOS/TAC might help to assess the progress of the disease and the potential effectiveness of antioxidant therapy.
\end{abstract}

Key words: lamin deficiency, oxidative stress, Emery-Dreifuss muscular dystrophy.

\section{Introduction}

A deficit of lamins $\mathrm{A} / \mathrm{C}$ or emerin in skeletal muscles and the heart causes a rare, genetically transmitted disease known as Emery-Dreifuss muscular dystrophy (EDMD). The cell defect is generalized, but skeletal muscles, heart and joints are all selectively affected, with the ultimate effects being skeletal muscle atrophy, joint contractures and dilated cardiomyopathy, which is at the onset either clinically silent or preceded by conduction block and arrhythmias $[13,14]$. Sudden death both in patients and in carriers is not a rare event.
Lamins serve as mediators of oxidative stress [20]. There is a relationship between lamin mutations and altered metabolism of radical oxygen species (ROS). Laminopathies are correlated with oxidative stress at the cellular level. No data have hitherto been available on antioxidant/oxidant status in EDMD.

The aim of the study described here was therefore to assess serum for total oxidant status (TOS), which represents the oxidative/antioxidative balance. The antioxidant capacity (TAC) measures the total antioxidant capacity of biomolecules. The relevant 
data obtained were compared to the clinical status of the EDMD patients.

\section{Material and methods}

A total of 29 patients with EDMD were examined. Twelve of these had autosomal-dominant EDMD associated with laminopathy (AD-EDMD), while 17 had X-linked EDMD (X-EDMD) associated with emerinopathy. The diagnoses of EDMD were confirmed clinically, by indirect immunofluorescence analysis of muscle nuclei, immunochemically by Western blotting examination of a muscle biopsy specimen, as previously described [5,15], and by molecular testing of LMNA and EMD genes, respectively (Tables I and II). Dilated cardiomyopathy was present in all the cases. However, no subjective cardiac symptoms, even when there was evident bradycardia, were present. In some patients cardiac involvement was already detected at the time of the first neurological examination. In AD-EDMD patients the left ventricle was affected. There were also disturbances of contractility or conductivity (Table I). Dilated cardiomyopathy was a feature common to all studied cases detected already at the first examination. Cardiac symptoms appeared earlier in the AD-EDMD than in the X-EDMD group. In the latter cardiac involvement was moderate/mild overall, to severe/very severe in some cases (Table II). With disease onset, conductance and atrial involvement predominate, necessitating implantation of a pacemaker in the majority of patients. In the follow-up clinical examination dilated cardiomyopathy was found to develop later in X-EDMD than AD-EDMD sufferers.

The control group consisted of 20 healthy agematched subjects with no history of muscle or cardiac disease.

Blood was selected for routine biochemical analyses and centrifuged at $3000 \mathrm{rpm}$ for 10 minutes. Serum was separated and frozen at $-30^{\circ} \mathrm{C}$ until used, usually up to 30 days both in patients and controls.

Table I. Clinical and laboratory data in individual autosomal-dominant Emery-Dreifuss muscular dystrophy (AD-EDMD) patients

\begin{tabular}{|c|c|c|c|c|c|c|c|c|c|c|c|c|}
\hline $\begin{array}{l}\text { No., } \\
\text { Sex }\end{array}$ & $\begin{array}{l}\text { Family } \\
\text { history }\end{array}$ & Mutation & $\begin{array}{l}\text { LAD } \\
(\mathrm{mm})\end{array}$ & $\begin{array}{l}\text { LVDD } \\
(\mathrm{mm})\end{array}$ & $\begin{array}{l}\mathrm{EF} \\
(\%)\end{array}$ & $\begin{array}{c}\text { Type } \\
\text { of arrhythmia }\end{array}$ & $\begin{array}{c}\text { Cardiac } \\
\text { device (age) }\end{array}$ & $\begin{array}{l}\text { Overall course } \\
\text { of the disease }\end{array}$ & $\begin{array}{l}\text { Muscle } \\
\text { atrophy }\end{array}$ & $\mathrm{C} / \mathrm{SR}$ & $\begin{array}{c}\text { TAC } \\
(\mathrm{mM} / \mathrm{l})\end{array}$ & $\begin{array}{c}\text { TOS } \\
(\mu \mathrm{M} / \mathrm{l})\end{array}$ \\
\hline $1 M$ & S & c. $1357 C>T$ & 31 & 42 & 52 & $\begin{array}{c}\text { SVEB, SVT, VEB, } \\
\text { AVB1 }\end{array}$ & ICD (36) & Severe & Arms, thighs & $+/+$ & 69 & 2.0 \\
\hline $2 \mathrm{M}$ & $\mathrm{F}$ & c. $1357 C>T$ & 44 & 63 & 36 & $\begin{array}{l}\text { AVB 1,2,3, atrial } \\
\text { standstill, nsVT }\end{array}$ & $\begin{array}{c}\text { Pacemaker } \\
(35) \\
\text { ICD (44) }\end{array}$ & Severe & Arms, thighs & $+/+$ & 55 & 6.2 \\
\hline $3 F$ & $\mathrm{~F}$ & $1357 C>T$ & 25 & 43 & 61 & SVEB, SVT & ICD (21) & Moderate & Generalized & $+/+$ & 12 & 9.8 \\
\hline $4 \mathrm{~F}$ & $S$ & c.1337A $>T$ & 26 & 35 & 61 & SVEB & No & Severe & Generalized & $+/+$ & 161 & 3.1 \\
\hline $5 \mathrm{M}$ & $\mathrm{F}$ & C. $1355 T>C$ & 29 & 40 & 50 & No arrhythmia & No & Mild & Arms, thighs & $+/+$ & 71 & 6.4 \\
\hline $6 \mathrm{M}$ & $\mathrm{F}$ & c.1355T>C & 43 & 51 & 45 & AVB $\| 2: 1$, VEB & $\begin{array}{l}\text { Pacemaker } \\
\text { (31) }\end{array}$ & Mild & Arms & $+/+$ & 31 & 9.95 \\
\hline $7 F$ & $\mathrm{~F}$ & C. $1355 T>C$ & 32 & 40 & 64 & No arrhythmia & No & Mild & No & $+/+$ & 93 & 3.7 \\
\hline $8 \mathrm{~F}$ & S & c. $1072 \mathrm{G}>\mathrm{A}$ & 37 & 54 & 44 & AVB 1/2/3, PAF & $\begin{array}{l}\text { Pacemaker } \\
\text { (25) }\end{array}$ & Severe & Generalized & $+/+$ & 96 & 3.1 \\
\hline $9 M$ & $\mathrm{~F}$ & c.743T>C & 30 & 51 & 55 & No arrhythmia & No & Moderate & Generalized & $+/-$ & 217 & 12.4 \\
\hline $10 \mathrm{~F}$ & $\mathrm{~F}$ & c. $1072 \mathrm{G}>\mathrm{A}$ & 30 & 46 & 68 & SVEB, VPB, AVB1 & No & Moderate & Generalized & $+/+$ & 112 & 4.7 \\
\hline $11 \mathrm{~F}$ & $\mathrm{~F}$ & $\begin{array}{l}\text { c.334- } \\
\text { 336del }\end{array}$ & 35 & 47 & 60 & $\begin{array}{c}\text { AVB1, PAF, SVEB, } \\
\text { SVT, tachy-brady, } \\
\text { nsVT }\end{array}$ & $\begin{array}{c}\text { Pacemaker } \\
(20) \\
\text { ICD (28) }\end{array}$ & Severe & Generalized & $+/+$ & 32 & 3.95 \\
\hline $12 \mathrm{M}$ & F & c. $743 T>C$ & $\begin{array}{l}\text { No } \\
\text { data }\end{array}$ & & & No arrhythmia & No & Mild & Arms, thighs & $+/+$ & 217 & 12.8 \\
\hline
\end{tabular}

C/SR - contractures/spine rigidity, SVT - supraventricular tachycardia, SVEB - supraventricular ectopic beats, AVB - atrio-ventricular block, ICD - implanted cardioverter/defibrillator, PAF - paroxysmal atrial fibrillation, VPB - ventricular premature beats, VEB - ventricular ectopic beats, LAD (left atrium diameter) - N: 19-40 mm, LVDD (left ventricle end diastolic diameter) - N: 35-57 mm, EF (ejection fraction) - N: 60-65\% 
Total oxidant status was determined using a Real Assay Diagnostics kit 4. The total antioxidant capacity was determined using an OxiSelect kit (Cell Biolabs, Inc.) [8]. Routine hematoxylin-eosin staining, antilamin and anti-emerin staining and Western blotting muscle biopsy with anti-lamin and anti-emerin antibodies [16] were also performed.

\section{Statistical analysis}

Analyses were performed using the commercial statistical package Statistica ver. 9.0. In line with the non-normal data distribution the medians and interquartile ranges are presented. The KruskalWallis analysis of variance was applied, followed by the Mann-Whitney $U$ test for a two-group comparison. The relationships among variables were analyzed by Spearman's correlation coefficients. Analysis of the receiver-operating characteristic (ROC) curves was also performed. The probability value of $p<0.05$ was regarded as statistically significant.

\section{Results}

Levels for serum TOS and total TAC reflect the redox balance between antioxidation and oxidation in EDMD. Total antioxidant capacity values in serum were significantly below those of the control in the cases of both EDMD groups, being at the level of $83.3 \%$ of patients in the case of AD-EDMD and $82.4 \%$ of patients in the case of X-EDMD (Table III). Slightly decreased values were present in both groups in 16.7 and $17.6 \%$ of the patients, respectively (appearing especially in mildly progressing cases). The values of TOS were also reduced in the EDMD patients (Table III). The ROC analysis demonstrated that the area under the curve (AUC) value of serum TAC equals 0.890, while the AUC value for TOS reached 1.000 (Fig. 1). No correlation was observed between TAC, TOS, and the cardiological or neurological parameters. A relationship between TOS level and disease progression was observed (Table IV, $p=0.032$ ).

Table II. Clinical and laboratory data in individual X-linked Emery-Dreifuss muscular dystrophy (X-EDMD) patients

\begin{tabular}{|c|c|c|c|c|c|c|c|c|c|c|c|c|}
\hline $\begin{array}{l}\text { No., } \\
\text { Sex }\end{array}$ & $\begin{array}{l}\text { Family } \\
\text { history }\end{array}$ & Mutation & $\begin{array}{l}\text { LAD } \\
(\mathrm{mm})\end{array}$ & $\begin{array}{l}\text { LVDD } \\
(\mathrm{mm})\end{array}$ & $\begin{array}{l}\mathrm{EF} \\
(\%)\end{array}$ & $\begin{array}{c}\text { Type } \\
\text { of arrhythmia }\end{array}$ & $\begin{array}{l}\text { Pacemaker } \\
\text { (age) }\end{array}$ & $\begin{array}{l}\text { Overall course } \\
\text { of the disease }\end{array}$ & $\begin{array}{l}\text { Muscle } \\
\text { atrophy }\end{array}$ & $\mathrm{C} / \mathrm{SR}$ & $\begin{array}{c}\text { TAC } \\
(\mathrm{mM} / \mathrm{l})\end{array}$ & $\begin{array}{c}\text { TOS } \\
(\mu \mathrm{M} / \mathrm{l})\end{array}$ \\
\hline $1 M$ & F & $c .1 A>G$ & 30 & 45 & 69 & AVB1 & No & Moderate & Arms, calves & $+/+$ & 29 & 0.6 \\
\hline $2 \mathrm{M}$ & $\mathrm{F}$ & $c .1 A>G$ & 32 & 46 & 54 & SVEB & No & Mild & Arms, calves & $+/+$ & 20 & 5.95 \\
\hline $3 \mathrm{M}$ & S & $c .1 A>G$ & 42 & 57 & 58 & $\mathrm{FA}, \mathrm{AVB}$ & Yes (25) & Moderate & Arms, calves & $+/+$ & 8 & 1.7 \\
\hline $4 \mathrm{M}$ & S & c. $256 C>T$ & 40 & 62 & 40 & AVB3, VEB & Yes (20) & Severe & Arms, thighs & $+/+$ & 15 & 2.5 \\
\hline $5 \mathrm{M}$ & $\mathrm{F}$ & $c .1 A>G$ & 30 & 47 & 55 & SVEB, SVT & No & Severe & Generalized & $+/+$ & 44 & 7.2 \\
\hline $6 \mathrm{M}$ & $\mathrm{F}$ & c.153delC & 38 & 50 & 56 & SVEB AF, SAB, & Yes (25) & Moderate & Arms & $+/+$ & 83 & 2.96 \\
\hline 7M & $\mathrm{F}$ & c.153delC & 31 & 51 & 52 & AF, AVB3 & Yes (31) & Moderate & Arms & $+/+$ & 62 & 7.4 \\
\hline $8 \mathrm{M}$ & $\mathrm{F}$ & c.153delC & 37 & 56 & 45 & tachy-brady & Yes (28) & Moderate & No atrophy & $-1+$ & 302 & 6.2 \\
\hline $9 M$ & S & c.153delC & $\begin{array}{l}\text { No } \\
\text { data }\end{array}$ & & & PAF & Yes (19) & Moderate & Generalized & $+/+$ & 12 & 1.4 \\
\hline $10 \mathrm{M}$ & $\mathrm{F}$ & c.153delC & 34 & 52 & 68 & $A V B 2 / 3, A F$ & Yes (21) & Moderate & Generalized & $+/+$ & 19 & 8.8 \\
\hline $11 \mathrm{M}$ & $\mathrm{F}$ & $c .187+1 G>A$ & 27 & 44 & $\begin{array}{l}\text { No } \\
\text { data }\end{array}$ & AVB3 & Yes (15) & Moderate & Arms, calves & $+/+$ & 57 & 0.96 \\
\hline $12 \mathrm{M}$ & $\mathrm{F}$ & $c .187+1 G>A$ & 43 & 53 & 50 & atrial standstill & Yes (35) & Mild & Arms & $+/-$ & 221 & 7.1 \\
\hline $13 \mathrm{M}$ & $\mathrm{F}$ & $\begin{array}{c}\text { c.266- } \\
\text { 27del18 }\end{array}$ & $\begin{array}{l}\text { No } \\
\text { data }\end{array}$ & 46 & 76 & SVEB, SVT & No & Moderate & Arms, calves & $+/+$ & 334 & 1.4 \\
\hline $14 \mathrm{M}$ & $\mathrm{F}$ & c.399+1G>C & 35 & 53 & 65 & tachy-brady & Yes (16) & Moderate & Arms, calves & $+/+$ & 18 & 9.4 \\
\hline $15 \mathrm{M}$ & F & c.397C>T & 33 & 49 & 54 & AVB $1 / 2 / 3$, AFL & Yes (25) & Moderate & Arms, calves & $+/+$ & 161 & 2.6 \\
\hline $16 \mathrm{M}$ & $\mathrm{F}$ & $c .3 \mathrm{G}>\mathrm{A}$ & 34 & 45 & 65 & AVB 1/2/3 PAF & Yes (30) & Mild & Arms & $-1+$ & 19 & 2.4 \\
\hline $17 \mathrm{M}$ & $\mathrm{F}$ & $\begin{array}{c}\text { c.450- } \\
\text { 451insG }\end{array}$ & 34 & 57 & 56 & $\begin{array}{l}\text { AVB1, VEB, } \\
\text { SAB }\end{array}$ & Yes (18) & Severe & Generalized & $+/+$ & 71 & 5.5 \\
\hline
\end{tabular}

C/SR - contractures/spine rigidity, AF - atrial fibrillation, AFL - atrial flutter, SVT - supraventricular tachycardia, SVEB - supraventricular ectopic beats, AVB - atrio-ventricular block, PAF - paroxysmal atrial fibrillation, VEB - ventricular ectopic beats, LAD (left atrium diameter) - N: 19-40 mm, LVDD (left ventricle end diastolic diameter) - N: 35-57 mm, EF (ejection fraction) - N: 60-65\%. 
Table III. Total antioxidant capacity and total oxidant status in Emery-Dreifuss muscular dystrophy (EDMD) and controls

\begin{tabular}{|lcccc|}
\hline Parameters & Controls $(n=20)$ & EDMD $(n=29)$ & AD-EDMD $(n=12)$ & X-EDMD $(n=17)$ \\
\hline TAC $(\mathrm{mM} / \mathrm{l})$ & $232(204-236)$ & $\begin{array}{c}62(20-112) \\
\left({ }^{\mathrm{a}} p<0.00001\right)\end{array}$ & $\begin{array}{c}82(43-136) \\
\left({ }^{\mathrm{a}} p=0.00001\right)\end{array}$ & $\left({ }^{\mathrm{a}} p<0.0001,{ }^{\mathrm{b}} p=0.227\right)$ \\
\hline $\operatorname{TOS}(\mu \mathrm{M} / \mathrm{l})$ & $57(35-73)$ & $\begin{array}{c}4.7(2.5-7.2) \\
\left({ }^{\mathrm{a}} p<0.00001\right)\end{array}$ & $\begin{array}{c}5.5(3.4-9.9) \\
\left({ }^{\mathrm{a}} p<0.00001\right)\end{array}$ & $\left({ }^{\mathrm{a}} p<0.00001,{ }^{\mathrm{b}} p=0.080\right)$ \\
\hline
\end{tabular}

Values are medians and interquartile ranges.

$p$ values for ${ }^{a} E D M D$ groups vs. controls, ${ }^{b} A D$ - vs. X-EDMD

Table IV. Total antioxidant capacity, total oxidant status and progression of Emery-Dreifuss muscular dystrophy (EDMD)

\begin{tabular}{|lcccc|}
\hline Parameters & Controls $(n=20)$ & EDMD $(n=29)$ & Mild/moderate $(n=21)$ & Severe $(n=8)$ \\
\hline TAC $(\mathrm{mM} / \mathrm{l})$ & $232(204-236)$ & $62(20-112)$ & $62(19-112)$ & $63(44-129)\left({ }^{c} p=0.582\right)$ \\
\hline TOS $(\mu \mathrm{M} / \mathrm{l})$ & $57(35-73)$ & $4.7(2.5-7.2)$ & $6.2(3.0-8.8)$ & $2.8(1.7-3.5)\left({ }^{c} p=0.032\right)$ \\
\hline
\end{tabular}

values are medians and interquartile ranges.

$p$ values compared progress of ${ }^{c}$ severe $v$ s. mild/moderate
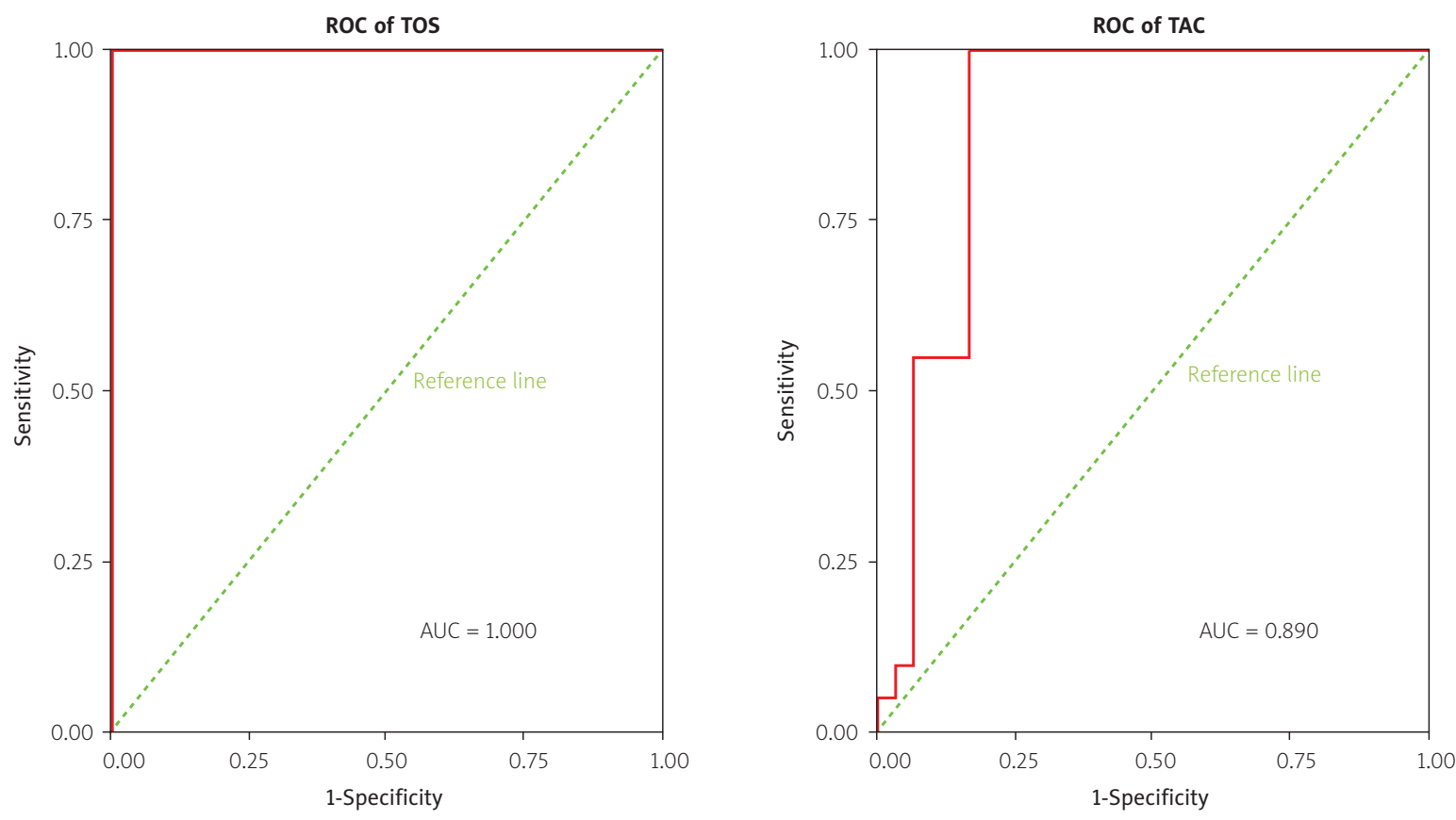

Fig. 1. Receiver-operating characteristic (ROC) curves for total oxidant status (TOS) and total antioxidant capacity (TAC) in Emery-Dreifuss muscular dystrophy patients.

\section{Discussion}

Free radicals are responsible for chemical modifications of and molecular changes in proteins, lipids, carbohydrates and nucleotides, as well as for modulation of gene expression. In biological membranes they induce changes in enzymes, and other proteins, as well as in the oxidation of - $\mathrm{SH}$ groups, the peroxidation of lipids, and the oxidation of polyunsaturated fatty acids. They also affect membrane transport systems. Accumulation of ROS can lead to DNA damage and the production of oxidized proteins $[16,18]$. Free radicals are also produced in different physiological processes under normal conditions. ROS action is typically limited by physiologically active antioxidant defense mechanisms [22]. Where the production of oxidative damaged molecules is enhanced, 
this is followed by an impairment of defense that leads to the accumulation of toxic products. Several chemical compounds are able to act as antioxidants; the impact is greater when the antioxidants are acting in a set $[8,21,22]$ and when glutathione, the most essential key agent in cell defense, is included $[1,24]$.

Lamina provides mechanical support for the nucleus [9], modulates gene expression [2,11,17], modulates the oxidative stress response [12], acts in intracellular redox homeostasis [20 ], and participates in transcription and chromatin organization [2] and DNA repair $[4,6,7]$. Laminopathies share features including defects in the DNA damage response [4]. In emerinopathies, apart from the deficit of emerin, a decrease of lamins is also noted [16].

A relationship between $L M N A$ mutation and altered ROS metabolism has already been proposed [19]. ROS have a direct damaging effect, affecting the lamin structure [16], and giving rise to persistent DNA damage [7] and telomere shortening [6]. In laminopathic cells during prelamin A accumulation ROS levels are elevated $[3,10,15]$. Persistent prelamin accumulation and lamin $\mathrm{A} / \mathrm{C}$ depletion are likewise associated with elevated ROS levels [20].

Details of redox biology in EDMD are not known, yet. When established it is likely to be helpful as regards both the introduction of early stage pharmacological treatment and decision-making in respect of cardiac device implantations and consideration even of heart transplantation. Thus far, the only TAC member assessed in EDMD has been blood glutathione, which is present in reduced amounts in EDMD with LMNA mutation, and is associated with early cardiac involvement [4]. More details of redox biology in EDMD may serve as a basis for prognoses regarding progression of the disease, as well as in monitoring for the effectiveness of an antioxidant therapy. Such therapy would be useful in restoring the balance between the production of free radicals and the antioxidant capacity, with resultant reduced severity of the disease.

The results presented here for TOS and TAC levels support the opinion that oxidative stress is involved in the pathogenesis of EDMD. This finding could lead to new directions of future therapeutic intervention.

\section{Acknowledgments}

Analyses were carried out using the computational infrastructure of the Biocentrum-Ochota project (POIG.02.03.00-00-0030/09).

\section{Disclosure}

Authors report no conflict of interest.

\section{References}

1. Adamy C, Mulder P, Khouzami L, Andrieu-Abadie N, Defer N, Candiani G, Pavoine C, Carmelle P, Souktani, Le Corvoisier P, Perier M, Kirsch M, Damy T, Berdeaux A, Levade T, Thuillez C, Hittinger L, Pecker F. Neutral sphingomyelinase inhibition participates to the benefits of $\mathrm{N}$-acetylcysteine treatment in post-myocardial infarction failing heart rats. J Mol Cell Cardiol 2007; 43: 344-353.

2. Andres V, Gonzales JM. Role of A-type lamins in signaling, transcription and chromatin organization. J Cell Biol 2009; 187: 945-957.

3. Barascu A, Le Chalony C, Pennarun G, Genet D, Zaarour N, Bertrand P. Oxidative stress alters nuclear shape through lamins dysregulation: a route to senescence. Nucleus 2012; 3: 411-417.

4. Dechat T, Pfleghaar K, Sengupta K, Shimi T, Shumaker DK, Solimando L, Goldman RD. Nuclear lamins: major factor in the structural organization and function of the nucleus and chromatin. Genes Dev 2008; 22: 832-853.

5. Fidziańska A, Niebroj-Dobosz I, Madej-Pilaczyk A, Duong NT, Wehnert M. X-linked Emery-Dreifuss muscular dystrophy with lamin A deficiency and IBM inclusions. Clin Neuropathol 2010; 29: 78-83.

6. Gonzalez-Suarez J, Redwood AB, Perkins SM, Verimolen B, Lichtensztejin D, Grotsky DA Morgado-Palacin L, Gapud EJ, Sleckman BP, Sullivan T, Sage J, Stewart CL, Mai S, Gonzalo S. Novel roles for A-type lamins in telomere biology and the DNA damage response pathway. EMBO I 2009; 28: 2414-2427.

7. Hutchison CJ. The role of DNA damage in laminopathy progeroid syndromes. Biochem Soc Trans 2011; 39: 1715-1718.

8. Koracevic D, Koracevic G, Djordejevic V, Andrejevic S, Cosic V. Method for measurement of antioxidant activity in human fluids. J Clin Pathol 2001; 54: 356-361.

9. Lammerding J, Schulze PC, Takahashi T, Kozlov S, Sullivan T, Kamm RD, Stewart CL, Lee RT. Lamin deficiency cases defective nuclear mechanics and mechanotransduction. J Clin Invest 2004; 113: 317-378.

10. Lattanzi G, Marmiroli S, Facchini A, Maraldi MN. Nuclear damages and oxidative stress: new perspectives for laminopathies. Eur J Histochem 2012; 56: e45.

11. Malhas AN, Lee CF, Vaux DJ. Lamin B1 controls oxidative stress response. J Cell Biol 2009; 184: 45-55.

12. Malhas AN, Vaux DJ. The nuclear envelope and its involvement in cellular stress response. Biochem Soc Trans 2011; 39: 195-198.

13. Madej-Pilarczyk A, Kontruchow K, Kabzińska D, Cegielska J, Kochanski A, Hausmanowa-Petrusewicz I. Emery-Dreifuss muscular dystrophy type 2 associated (?) with mild peripheral polyneuropathy. Folia Neuropathol 2015; 53: 270-274.

14. Madej-Pilarczyk A, Kochański A. Emery-Dreifuss muscular dystrophy; the most recognizable laminopathy. Folia Neuropathol 2016; 54: 1-8.

15. Niebroj-Dobosz I, Fidziańska A, Hausmanowa-Petrusewicz I. Expression of emerin and lamins in muscle of patients with different forms of Emery-Dreifuss muscular dystrophy. Acta Myol 2003; 22: 52-57. 
16. Pekovic V, Gibbs-Seymour I, Markiewicz E, Alzoghaibi F, Benham AM, Edwards R, Wenhert M, von Zglinicki T, Hutchison C). Conserved cysteine residues in the mammalian lamin A tail are essential for cellular responses to ROS generation. Aging Cell 2011; 10: 1067-1079.

17. Reddy KL, Zullo E, Bertolino E, Singh H. Transcriptional repression mediated by repositioning of genes to the nuclear lamina. Nature 2008; 452: 243-247.

18. Richards SA, Muter J, Ritchie P, Lattanzi G, Hutchinson CJ. The accumulation of un-repairable DNA damage in laminopathy progeria fibroblasts is caused by ROS generation and is prevented by treatment with N-acetyl cysteine. Hum Mol Genet 2011; 20: 3997-4004.

19. Sieprath T, Darwiche R, De Vos WH. Lamins as mediators of oxidative stress. Biochem Biophys Res Commun 2012; 421: 635-639.

20. Sieprath T, Corne TD, Nooteboom M, Grootaert C, Rajkovic A, Buysschaert B, Robijns J, Broers JV, Ramaekers FC, Koopman WJ, Willems PH, De Vos WH. Sustained accumulation of prelamin $A$ and depletion of lamin A/C both cause oxidative stress and mitochondrial dysfunction but induce different cell fates. Nucleus 2015; 6: 236-246.

21. Wayzner DM, Burton GW, Ingold KU, Barclay LP, Locke SJ. The relative contributions of vitamin $\mathrm{E}$, urate, ascorbate, and proteins to the total peroxyl radical-trapping antioxidant activity of human blood plasma. Biochim Biophys Acta 1987; 924 408-419.

22. Woodford FP, Whitehead TP. Is measuring serum antioxidant capacity clinically useful? Ann Clin Biochem 1998; 35: 48-56.

23. Yucel D, Aydogdu S, Cehreli S, Saydam G, Canatan H, Senes M, Topkaya B, Nebioglu S. Increased oxidative stress in dilated cardiomyopathic heart failure. Clin Chem 1998; 44: 148-154. 